\title{
Isolation of endophytic bacteria from the leaves of Anredera cordifolia CIX1 for metabolites and their biological activities
}

Celiwe Innocentia Nxumalo, Londeka Sibusisiwe Ngidi ${ }^{*}$ (D, Jabulani Siyabonga Emmanuel Shandu and

Tsolanku Sidney Maliehe

\begin{abstract}
Background: Endophytes, especially those that are found from ethnopharmacologically noteworthy medicinal plants have attracted attention due to their diverse bioactive metabolites of pharmacological importance.

Methods: This study aimed at isolating endophytic bacterium from the leaves of Anredera cordifolia CIX1 for its bioactive metabolites. The endophytic isolates were identified by $16 \mathrm{~S}$ rRNA sequence and investigated for antibiotic sensitivity using different antibiotics. The secondary metabolites were evaluated for antibacterial activity against four bacterial strains. The 2-diphenyl-1-picrylhydrazyl (DPPH) and 2, 2'-azinobis (3- ethylbenzothiazoline-6-sulfonic acid) (ABTS) methods were used to assess their scavenging activities. The chemical components were analysed by gas chromatography-mass spectrometry (GC-MS).

Results: Out of 13 isolates, Isolate 1 was identified as Pseudomonas aeruginosa CP043328.1. It was resistant to clindamycin, ertapenem, penicillin G, amoxicillin, cephalothin and kanamycin but sensitive to imipenem, meropenem, and gentamycin. Its extract demonstrated antibacterial activity with minimum inhibitory concentration value of 0.098 against Bacillus cereus (ATCC 10102) and Staphylococcus aureus (ATCC 25925) and $0.391 \mathrm{mg} / \mathrm{ml}$ against Escherichia coli (ATCC 25922) and Proteus mirabilis (ATCC 25933). The extract revealed DPPH and ABTS scavenging activities with half maximal inhibitory concentration value of $0.650 \mathrm{mg} / \mathrm{ml}$ and $0.15 \mathrm{mg} / \mathrm{ml}$, respectively. The GC-MS revealed a total of 15 compounds with diisooctyl phthalate $(50.51 \%)$ and $[1,2,4]$ oxadiazole, 5-benzyl-3 (10.44\%) as major components.
\end{abstract}

Conclusions: P. aeruginosa CP043328.1 produced secondary metabolites with antibacterial and antioxidant activities.

Keywords: Pseudomonas aeruginosa CP043328.1, Antibacterial activity, Antioxidant activity, Volatile compounds

\section{Background}

South Africa has remarkable successes in treatment of infectious diseases that include HIV and TB, malaria and others. This is evidenced by the increase in life expectancy over the years. The increase stems from the implementation of some health initiatives that include the use

\footnotetext{
* Correspondence: londekangidi@gmail.com

Faculty of Science and Agriculture, Department of Biochemistry and Microbiology, University of Zululand, Private Bag X1001, KwaDlangezwa, KwaZulu Natal Province 3886, South Africa
}

of antiretroviral agents for people living with HIV [1]. Although an outstanding progress has been made in reducing morbidity and mortality rates due to infectious diseases, new microbial resistance mechanisms threaten prevention and treatment procedures [2]. This is due mainly to inadequate dosing, poor quality drugs, and genetic plasticity of the microorganisms [3]. Without effective antimicrobial agents, the success of even minor surgeries can be of a great challenge [4]. Therefore, joint efforts to discover and develop new drugs is imperial.

C C The Author(s). 2020 Open Access This article is licensed under a Creative Commons Attribution 4.0 International License, which permits use, sharing, adaptation, distribution and reproduction in any medium or format, as long as you give appropriate credit to the original author(s) and the source, provide a link to the Creative Commons licence, and indicate if changes were made. The images or other third party material in this article are included in the article's Creative Commons licence, unless indicated otherwise in a credit line to the material. If material is not included in the article's Creative Commons licence and your intended use is not permitted by statutory regulation or exceeds the permitted use, you will need to obtain permission directly from the copyright holder. To view a copy of this licence, visit http://creativecommons.org/licenses/by/4.0/ The Creative Commons Public Domain Dedication waiver (http://creativecommons.org/publicdomain/zero/1.0/) applies to the data made available in this article, unless otherwise stated in a credit line to the data. 
Medicinal plants are the predominant sources for bioactive compounds used in modern-day drug discoveries and developments [5]. Over $80 \%$ of drugs on the market shelves currently have their origin in medicinal plants [6]. Although plant metabolites exhibit strong physiological activities, their production are not of convenience in terms of quality and productivity due to hysterical environmental conditions and rapid climatic changes [7]. Thus, bioprospecting of bioactive metabolites from microorganisms have become a promising alternative route for drug discovery [8].

Microorganisms such as bacteria and fungi can produce high quality metabolites on a large scale under optimized culture conditions [9]. This is because their metabolite production is reproducible, weather and season independent [10]. Microorganisms often produce metabolites that display distinctive molecular skeletons which are not even available in the chemical libraries [11]. Endophytes are microorganisms which inhabit within plant tissues and often occur as symbionts [12]. Endophytes, especially those that are found from ethnopharmacologically noteworthy medicinal plants have attracted attention due to their diverse bioactive metabolites against pathogens [13]. They produce a plethora of metabolites with unique structures and profound biological activities. These include essential enzymes, alkaloids, flavonoids, phenolic acids, quinines, steroids and terpenoids. Although these metabolites were primarily beneficially to the host plant, they have found a wideranging application industrially. They are harvested and used as agrochemicals, antibiotics, immunosuppressants and antioxidants [14]. Nevertheless, most of research focuses on fungal-based bioactive products and a limited number has been isolated from bacterial endophyte [15].

Anredera cordifolia is a well-recognized medicinal plant that belong to Basellaceae family. A. cordifolia possesses pharmacological activities such as antibacterial [16], gastroprotective [17], antivirus [18], antidiabetic [19], antiinflammatory [20], wound healing [21] and antioxidant [22]. Phytochemical screening has revealed the presence of flavanols [18], glycosides, alkaloids [23], flavonoids [24], saponin and steroid [19] in different parts. Although there are many studies documenting its medicinal properties and usage, to the best of our knowledge, there are no studies reporting on its bacterial endophytes.

The study was designed to isolate and identify endophytic bacteria from $A$. cordifolia. The bacteria were screened for extracellular enzyme and antimicrobial agent production. Moreover, its biological activities such as antibacterial and antioxidant activities were evaluated from the extracted secondary metabolites of one of the isolates. Lastly, metabolites composition was analysed. The other isolated bacteria will be investigated in future studies.

\section{Methods}

\section{Chemicals and media}

All chemicals and media used were procured from Sigma-Aldrich and Merck (Pty) Ltd. The water used was distilled and autoclaved.

\section{Sample collection and treatment}

Healthy fresh leaves of Anredera cordifolia were collected on the 2nd of July 2019 from KwaDlangezwa area in the city of Umhlathuze, KwaZulu-Natal Province, South Africa $\left(28^{\circ} 45^{\prime} \mathrm{S} 31^{\circ} 54\right.$ 'E). The voucher specimen for $A$. cordifolia species, voucher number CIX1, was prepared and deposited in the University of Zululand Herbarium [ZULU], which is available mainly to researchers. The leaves were washed thoroughly under running tap water and air dried. The surfaces of the leaves were disinfected by dipping them in $75 \%$ ethanol for $5 \mathrm{~min}$, followed by dipping in sodium hypochlorite $(2 \% \mathrm{w} / \mathrm{v}$ $\mathrm{NaOCl}$ ) for $4 \mathrm{~min}$ [10]. They were further dipped in sodium bicarbonate (10\% NaHCO3) for 2 min and subsequently rinsed in sterile distilled water six times. The excess water was dried under laminar airflow chamber. To confirm the disinfection process, aliquots of the sterile water used in the final rinse were plated onto nutrient agar (NA). The plates were then incubated at $28^{\circ} \mathrm{C}$ for 5 days and observed for any microbial growth [25].

\section{Isolation of endophytic bacteria}

NA was used for the isolation of the endophytic bacteria. The disinfected leaves, without midribs, were ground in sterile $6 \mathrm{ml}$ of aqueous saline solution $(0.9 \% \mathrm{NaCl})$ using a sterile mortar, under aseptic conditions. The tissue extract was serially diluted in sterile aqueous solution. About $100 \mu \mathrm{l}$ of each dilute $\left(10^{-1}\right.$ and $\left.10^{-2}\right)$ and undiluted sample were pipetted on NA plates and spread evenly using a sterilized glass spreader. Plates were sealed and incubated at $28^{\circ} \mathrm{C}$ for 5 days. The colonies were counted as colony forming units (CFU) per gram and expressed as population density. The colonies were selected based on divergence in morphology, size and colour. They were then sub-cultured twice on NA and stored at $4{ }^{\circ} \mathrm{C}[16]$.

\section{Screening for enzyme production Amylase production}

The amylase production was investigated by starch agar plate method. Briefly, NA medium was supplemented with $1 \mathrm{~g} / \mathrm{L}$ of starch. One microliter of the isolates was inoculated onto the medium and incubated at $28^{\circ} \mathrm{C}$ for 5 days. The positive controls were Escherichia coli (ATCC 25922) and Bacillus cereus (ATCC 10102) while autoclaved distilled water served as a negative control. The plates were then flooded with Gram's dye solution. 
The presence of halos around the colonies were indicative amylase production [26].

\section{Proteinase production}

Proteolytic production of the bacterial strains was assessed on protease casein medium that contained NA supplemented with $1 \%$ casein. One microliter of each isolate was pipetted on the plate and incubated at $28^{\circ} \mathrm{C}$ for 5 days. The positive control was Bacillus cereus (ATCC 10102) while autoclaved distilled water served as a negative control. After incubation time, the clear zones due to casein hydrolysis were considered as an indication of protease production [27].

\section{Cellulase production}

Carboxy methyl cellulase production was evaluated using the method by Zamani et al. [28]. The NA supplemented with $1 \%$ of carboxy methyl cellulose was inoculated with the isolates and incubated for 5 days at $28^{\circ} \mathrm{C}$. The negative control was Escherichia coli (ATCC 25922) while Cellulomonas humilata ATCC 2517 served as the positive control. The plates were then flooded with a solution of $0.5 \%$ Congo red. Isolates forming yellow coloured zones were considered positive for cellulase activity.

\section{Esterase production}

The medium containing peptone $10.0 \mathrm{~g} / \mathrm{L}, \mathrm{NaCl} 5.0 \mathrm{~g} / \mathrm{L}$, $\mathrm{CaCl} 2.2 \mathrm{H} 2 \mathrm{O} 0.1 \mathrm{~g} / \mathrm{L}$, agar $18.0 \mathrm{~g} / \mathrm{L}, \mathrm{pH} 7.0$ was prepared for determining esterase activity. To the sterilized culture medium, previously sterilized Tween $80(1 \%(\mathrm{v} / \mathrm{v})$ was added. Endophytic bacterial isolates, E. coli (ATCC 25922) (negative control) and Bacillus cereus (ATCC 10102) (positive control) were separately pipetted onto the medium and incubated at $28^{\circ} \mathrm{C}$ for 5 days. After incubation period, the appearance of a well visible halo around the colonies was indicative of the esterase production [29].

\section{Screening for antimicrobial agents production}

Pure endophytic bacterial isolates were pre-cultured overnight on NA at $37^{\circ} \mathrm{C}$. A loopful of fresh endophytic bacterial species were inoculated into $100 \mathrm{ml}$ Erlenmeyer flask containing $50 \mathrm{ml}$ of sterilised nutrient broth (NB). They were incubated at $28^{\circ} \mathrm{C}, 130 \mathrm{rpm}$ for $72 \mathrm{~h}$. Two millilitres of the fermented broth were centrifuged at $13000 \mathrm{rpm}$ for $15 \mathrm{~min}$. The culture supernatant was used for screening of antibacterial activity. An agar well diffusion method was employed to screen antibacterial activity of the isolates in accordance to [30]. Briefly, test bacterial inoculums Bacillus cereus (ATCC 10102), Staphylococcus aureus (ATCC 25925), Proteus mirabilis (ATCC 25933) and Escherichia coli (ATCC 25922) were adjusted to $106 \mathrm{CFU} / \mathrm{ml}$. The test bacterial strains were streaked on Mueller Hinton $(\mathrm{MH})$ agar with sterile swabs over the agar surface. About $6 \mathrm{~mm}$ diameter wells were made on the bacterial lawn using sterile cork borer. A total of $100 \mu \mathrm{l}$ of the centrifuged endophyte brothssupernatants was pipetted into the wells. $\mathrm{MH}$ broth was set as negative control and ciprofloxacin $(20 \mu \mathrm{g} / \mathrm{ml})$ as a positive control. The plates were left at room temperature for $10 \mathrm{~min}$ to allow the diffusion of the supernatants into the agar. They were then sealed and incubated at $37^{\circ} \mathrm{C}$. After $24 \mathrm{~h}$, the plates were observed for the inhibition of the selected bacteria. The zone of inhibition was measured and expressed in millimetres as an indication of antibacterial activity.

\section{Morphological identification of endophytic bacteria}

Pure bacterial colonies were subjected to Gram staining to investigate their morphological physiognomies such as shape and Gram stain reaction. Briefly, the bacterial isolates were spread on the glass slides and heat fixed using Bunsen burner. The crystal violet was used as a primary stain, followed by iodine solution. It was decolorized by ethanol after washing with tap water. The slides were flooded with safranin and rinsed with tap water. Lastly, the slides were viewed at $1000 \mathrm{X}$ magnification using a compound bright- field microscope [31].

\section{Molecular identification of endophytic bacteria}

Five isolates (Isolate 1-5) were further identified using $16 \mathrm{~S}$ rRNA sequence analysis by Inqaba Biotechnical Industries (Pty) Ltd. Briefly, DNA extraction was done using a ZR Fungal/Bacterial $\mathrm{Kit}^{\mathrm{TM}}$ according to the manufacturer's instructions. Polymerase chain reaction (PCR) was run to amplify the $16 \mathrm{~S}$ rDNA gene of the endophyte with the primers 16S- 27F: 5'AGAGTTTGATCMTGGCTCAG- 3' and 16S- 1492R: 5'- CGGT TACCTTGTTACGACTT-3', using DreamTaq ${ }^{\text {тм }}$ DNA polymerase. PCR products were gel extracted and sequenced in the forward and reverse directions on the ABI PRISM ${ }^{\mathrm{m}}$ 3500xl Genetic Analyser. The PCR products were cleaned with ExoSAP-it ${ }^{\mathrm{Tm}}$ following the manufacturer's recommendations. Purified sequencing products were analysed using CLC Bio Main Workbench v7.6, followed by a BLAST search using the National Center for Biotechnology Information (NCBI) database to identify the closest bacterial species [32].

\section{Sensitivity assay}

Antimicrobial susceptibility assay was performed using the Kirby-Bauer disk diffusion method. Different antimicrobial agent that include; clindamycin $2 \mu \mathrm{g}$, ertapenem $10 \mu \mathrm{g}$, imipenem $10 \mu \mathrm{g}$, kanamycin $30 \mu \mathrm{g}$, gentamicin $10 \mu \mathrm{g}$, cephalothin $5 \mu \mathrm{g}$, amoxicillin $10 \mu \mathrm{g}$ and meropenem $10 \mu \mathrm{g}$ were used. E. coli (ATCC 25922) and $P$. aeruginosa (ATCC 27853) served as the reference 
strains alongside the test strain. The zones of inhibition were interpreted in accordance to the Clinical Laboratory Standards Institute (CLSI) guidelines [33].

\section{Metabolites extraction}

The secondary metabolites from Isolate 1 were obtained by inoculating $200 \mu \mathrm{l}$ of bacterial suspension into $500 \mathrm{ml}$ of NB. The culture was incubated at $28^{\circ} \mathrm{C}$ for 5 days on a rotating shaker at $130 \mathrm{rpm}$. The broth culture was centrifuged at $5000 \mathrm{rpm}$ for $30 \mathrm{~min}$. The supernatant was collected and the pellet discarded. The supernatant was extracted with an equal volume of ethyl acetate $(500 \mathrm{ml})$ and then left overnight at $4{ }^{\circ} \mathrm{C}$. The solvent phase containing the extracted secondary metabolites was separated using separating funnel. The extract was evaporated using a rotary evaporator at $40{ }^{\circ} \mathrm{C}$ with 90 $\mathrm{rpm}$ to yield the crude metabolites. The residue was redissolved in methanol. The concentrated crude extract was then stored at $4{ }^{\circ} \mathrm{C}$ for further studies [34].

\section{Determination of antibacterial activity using crude extract Agar well diffusion}

Preliminary antibacterial activity of the crude extract was determined by agar diffusion method as described previously. Ten percent of DMSO was used as a negative control while ciprofloxacin $(20 \mu \mathrm{g} / \mathrm{ml})$ served as a positive control [32].

\section{Serial microdilution method}

The extract was submitted to further analysis to detect its minimum inhibitory concentration (MIC) using microdilution method [35]. The stock solution of 100 $\mathrm{mg} / \mathrm{ml}$ of the extract was prepared in $10 \%$ dimethyl sulfoxide (DMSO). Micro-serial dilution was carried out using $\mathrm{MH}$ broth in a range of $50-0.313 \mathrm{mg} / \mathrm{ml}$. About $100 \mu \mathrm{l}$ of the fresh selected bacterial suspension at a density of $1 \times 10^{6} \mathrm{CFU} / \mathrm{min}^{-1}$, was pipetted into the wells. Ten percent of DMSO was used as a negative control while ciprofloxacin $(20 \mu \mathrm{g} / \mathrm{ml})$ served as a positive control. The plates were sealed and incubated at $37^{\circ} \mathrm{C}$ overnight. Afterwards, $40 \mu \mathrm{l}$ of $0.2 \mathrm{mg} / \mathrm{ml}$ of piodonitrotetrazodium violet (INT) solution was added to each well and incubated at $37^{\circ} \mathrm{C}$ for $30 \mathrm{~min}$. The MIC was perceived as the lowest concentration of the extract that inhibited the bacterial growth.

\section{Evaluation of minimum bactericidal concentration (MBC)}

MBC was assessed by removing a loopful of each culture from the wells that had no bacterial growth. They were then streaked on different sterile $\mathrm{MH}$ agar plates. The agar plates were incubated at $37^{\circ} \mathrm{C}$ for $24 \mathrm{~h}$. The lowest concentration of the extract that exhibited the complete killing of the selected bacterial test species was considered as the MBC [36].

\section{2, 2-diphenyl-1-picrylhydrazyl (DPPH) radical scavenging assay}

The DPPH free radical scavenging activity of the extract was investigated in a sterile 96-well plate. The DPPH $(0.02 \mathrm{mg} / \mathrm{mL})$ was mixed $(1: 1 \mathrm{v} / \mathrm{v})$ with the extract at different concentrations. The mixtures were made to stand at room temperature $\left(25^{\circ} \mathrm{C}\right)$ for $30 \mathrm{~min}$ in darkness and the absorbance was read at $517 \mathrm{~nm}$ by using microplate reader. The extract without DPPH was used as the blank while ascorbic acid (AA) and butylated hydroxyl anisole (BHA) served as the positive controls. The percent inhibition of DPPH radical was measured by the using the formula: \%DPPH scavenging activity $=[$ Ao $-\mathrm{A} 1 / \mathrm{Ao}] \times$ 100 where, A1 and Ao equal the absorbance at $517 \mathrm{~nm}$ of the control and the test, respectively. The median inhibitory concentration $\left(\mathrm{IC}_{50}\right)$ of the extract against DPPH was calculated graphically [37].

\section{2, 2'-azino-bis-3-ethylbenzothiazoline-6-sulfonic acid (ABTS) radical scavenging assay}

The ABTS free radical scavenging activity of the extract was evaluated by using serial dilution method. ABTS solution $(0.003 \mathrm{~g} / \mathrm{mL})$ was mixed $(1: 1 \mathrm{v} / \mathrm{v})$ with the extract at different concentrations. Each mixture was made to stand for $15 \mathrm{~min}$ at $25^{\circ} \mathrm{C}$ and the absorbance was read at $734 \mathrm{~nm}$ by using microplate reader. The extract without ABTS solution served as blank. Ascorbic acid (AA) and butylated hydroxyl anisole (BHA) were used as the positive controls. The percent inhibition of ABTS radical was calculated by the following formula: \%ABTS scavenging activity $=[$ Ao - A1 / Ao $] \times 100$ where, A1 and Ao equal the absorbance recorded at $734 \mathrm{~nm}$ of the control and the test, respectively. The $\mathrm{IC}_{50}$ of the extract against ABTS was calculated graphically [38].

\section{Analysis of volatile compounds}

The components of the extract were analysed by using gas chromatography-mass spectrometry (GC-MS). The temperature of the $\mathrm{GC}$ oven was initially set at $40{ }^{\circ} \mathrm{C}$ for $3 \mathrm{~min}$ and subsequently increased by $5^{\circ} \mathrm{C}$ per minute to $220^{\circ} \mathrm{C}$. The temperature of the injector was programmed to $250^{\circ} \mathrm{C}$, and the flow rate of the helium gas was $1.0 \mathrm{ml}$ per minute, with a $10: 1$ split ratio. The ion source temperature of the MS system was put at $250{ }^{\circ} \mathrm{C}$ with the voltage of $70 \mathrm{eV}$. The evaluation was performed two times [39].

\section{Software and statistical analysis}

All the experimentations were done in triplicates and the data were subjected to one-way analysis of variance using Graph Pad Prism TM 6.1. Arrow bars represented the standard deviation and values with different alphabets represent the significant difference $(p<0.05)$. 


\section{Results}

\section{Isolation and surface sterilization}

The surface of the leaves was sterilised by sequentially immersing them in $70 \%$ ethanol, $2 \%$ sodium hypochlorite and $10 \%$ sodium bicarbonate. This protocol was effective as the control plates did not reveal any bacterial growth after 5 days. Nutrient agar plates inoculated with A. cordifolia leaf samples showed morphologically different colonies. The number of CFU per gram fresh weight of the isolates was investigated. The results showed that the leaves had $9.2 \times 103 \mathrm{CFU} / \mathrm{g}^{-1}$ (Table 1 ).

\section{Enzyme and antimicrobial agent production}

The isolates were all screened qualitatively on solid casein, cellulose, tween 80 and starch media for the four industrially important enzymes namely; proteases, cellulase, esterase and amylases. All isolates showed the ability to produce two or more of the tested enzymes. About 38, 62, 38 and $77 \%$ of the isolates produced proteinase, amylase, esterase and cellulase, respectively (Table 2). Isolate 1-5 showed the ability to produce all the tested enzymes. The isolates were further screened for antimicrobial agent production using broth fermentation cultures. Isolate 1 did also show broad spectrum against all tested clinical human pathogens (Table 2).

\section{Identification of the endophytes}

The isolates were selected for morphological characterization using Gram staining. Twelve isolates were Gram negative rods while one isolate was a Gram positive rod (Table 3). Molecular characterization of the endophytic bacteria indicate that they are different bacterial species. The final taxonomic status of 5 selected endophytic bacteria isolates was determined by $16 \mathrm{~S}$ rRNA gene sequencing. The sequence alignment showed the similarity in a range of $97-99 \%$ in BLAST with different strains of Pseudomonas aeruginosa namely; $P$. aeruginosa CP43328.1, P. aeruginosa CP033432.1, $P$. aeruginosa LR657304.1, P. aeruginosa CP044006.1 and P. aeruginosa CP032126.1 (Table 3).

\section{Susceptibility pattern of $P$. aeruginosa CP43328.1}

Based on the outstanding results showed by Isolate $1(P$. aeruginosa CP43328.1) during screening methods, Kirby-Bauer method was used to evaluate its susceptibility patterns using different antibiotics. The isolate was resistant to clindamycin, ertapenem, cephalothin,

Table 1 Endophytic bacterial population from the fresh leaves of A. cordifolia

\begin{tabular}{llll}
\hline Sample & $\begin{array}{l}\text { Un-diluted } \\
\left(\mathrm{CFU} / \mathbf{g}^{-1}\right)\end{array}$ & $\begin{array}{l}\mathbf{1 0}^{-\mathbf{1}} \\
\left(\mathrm{CFU} / \mathbf{g}^{-1}\right)\end{array}$ & $\begin{array}{l}\mathbf{1 0}^{-\mathbf{2}} \\
\left(\mathrm{CFU} / \mathbf{g}^{-\mathbf{1}}\right)\end{array}$ \\
\hline Leaves & $\mathrm{TN}$ & $\mathrm{TN}$ & $9.2 \times 10^{3}$ \\
\hline
\end{tabular}

TN denotes too numerous to count penicillin G, kanamycin and amoxicillin but sensitive to imipenem, meropenem and gentamycin (Table 4).

\section{Extraction of secondary metabolites}

Based on the outstanding results obtained during screening of enzymes and antibiotic production, secondary metabolites from Isolate 1 ( $P$. aeruginosa CP043328.1) were extracted. The isolate yielded $0.6 \mathrm{~g} / 500 \mathrm{ml}$ of the extract.

\section{Antibacterial activity of the extract}

The tests for the antibacterial potency of the extract was evaluated against the selected bacterial pathogens using the agar diffusion method and results are demonstrated in Table 5. The extract demonstrated significant inhibitory ability against all selected bacterial strains. It was mostly effective against $S$. aureus (ATCC 25925), with the maximum inhibition zone of $31 \pm 1.25 \mathrm{~mm}$.

Microdilution method was used to investigate the minimum inhibition concentration (MIC) of the extract. MIC of the secondary metabolites ranged from 0.098 $\mathrm{mg} / \mathrm{ml}$ to $0.39 \mathrm{mg} / \mathrm{ml}$. The profound antibacterial activity of the extract was against the Gram-positive bacteria B. cereus (ATCC 10102) and S. aureus (ATCC 25925) with MIC value of $0.098 \mathrm{mg} / \mathrm{ml}$ (Table 6). Although the extract was more pronounced against Gram positive bacterial strains, it also did demonstrate remarkable antibacterial activity against Gram negative bacteria $E$. coli (ATCC 25922) and P. mirabilis (ATCC 25933) with the MIC of $0.39 \mathrm{mg} / \mathrm{ml}$. Moreover, ciprofloxacin showed higher MIC value $(25 \mathrm{mg} / \mathrm{ml})$ against the tested strains when compared to the extract. Minimum bactericidal concentration (MBC) of the extract was evaluated against the selected bacterial strains. The extract showed only bactericidal effect against S. aureus (ATCC 25925) with the MBC of $25 \mathrm{mg} / \mathrm{ml}$ (Table 6).

\section{2, 2-diphenyl-1-picrylhydrazyl (DPPH) radical scavenging assay}

The scavenging activity of the extract against DPPH is shown in Fig. 1. The extract exhibited maximum DPPH scavenging activity of $63 \%$ at $1.0 \mathrm{mg} / \mathrm{ml}$. It also demonstrated the $\mathrm{IC}_{50}$ value of $0.650 \mathrm{mg} / \mathrm{ml}$, which was higher than that of ascorbic acid $(0.200 \mathrm{mg} / \mathrm{ml})$ and BHA $(0.188 \mathrm{mg} / \mathrm{ml})$.

\section{2, 2'-azino-bis-3-ethylbenzothiazoline-6-sulfonic acid (ABTS) radical scavenging assay}

The ABTS radical scavenging activity of the extract is shown in Fig. 2. The scavenging activity of the extract increased up to $91 \%$ at $0.5 \mathrm{mg} / \mathrm{ml}$. The extract had potent antioxidant activity with an $\mathrm{IC}_{50}$ value of $0.150 \mathrm{mg} /$ $\mathrm{ml}$. Ascorbic acid and BHA had $\mathrm{IC}_{50}$ of $0,258 \mathrm{mg} / \mathrm{ml}$ and $0,300 \mathrm{mg} / \mathrm{ml}$, respectively. 
Table 2 Enzyme and antimicrobial agent production

\begin{tabular}{|c|c|c|c|c|c|c|c|c|}
\hline \multirow[t]{2}{*}{ Isolates } & \multicolumn{3}{|c|}{ Enzyme production } & \multicolumn{3}{|c|}{ Zone of inhibition } & \multirow[b]{2}{*}{$\begin{array}{l}\text { B. cereus (ATCC } \\
\text { 10102) }\end{array}$} & \multirow[b]{2}{*}{$\begin{array}{l}\text { S. aureus (ATCC } \\
\text { 25925) }\end{array}$} \\
\hline & Proteinase & Amylase & $\overline{\text { Esterase }}$ & Cellulase & $\begin{array}{l}\text { E. coli (ATCC } \\
\text { 25922) }\end{array}$ & $\begin{array}{l}\text { P. mirabilis (ATCC } \\
\text { 25933) }\end{array}$ & & \\
\hline 1 & + & + & + & + & ++ & ++ & +++ & +++ \\
\hline 2 & - & + & + & + & ++ & - & ++ & ++ \\
\hline 3 & + & + & - & + & ++ & - & ++ & ++ \\
\hline 4 & - & + & + & + & - & ++ & + & +++ \\
\hline 5 & + & - & + & + & - & - & + & +++ \\
\hline 6 & - & + & - & + & - & - & + & + \\
\hline 7 & - & + & - & + & + & - & + & - \\
\hline 8 & + & - & + & - & + & - & ++ & ++ \\
\hline 9 & + & + & - & - & + & - & - & + \\
\hline 10 & - & - & - & + & - & - & + & + \\
\hline 11 & - & + & - & + & - & + & + & + \\
\hline 12 & - & + & - & - & - & + & ++ & +++ \\
\hline 13 & + & - & + & + & - & - & + & + \\
\hline
\end{tabular}

+ denotes enzyme production and - denotes no enzyme production. Inhibition zone diameter index: + ( $\leq 9 \mathrm{~mm})$ weak activity, ++ (10-20 mm) moderate activity, $+++(\geq 21 \mathrm{~mm})$ strong activity and -denotes no activity

\section{Analysis of bioactive compounds}

GC-MC chromatogram displayed a total of 15 compounds (Table 7). They are diisooctyl phthalate (50.51\%), 9octadecenamide (10.44\%), [1, 2, 4] oxadiazole, 5-benzyl-3(thiophen-2-yl) (5.70\%), 2-dodecenoic acid (5.51\%), trans-2decenoic acid (4.57\%), xanthoxylin (3.74\%), L-proline, Nvaleryl-, undecyl ester (2.86\%), L-proline, $\mathrm{N}$-valeryl-, tetradecyl ester (2.61\%), pyrrolo [1,2-a]pyrazine-1,4-dione, hexahydro-3-(2-methylpropyl) (2.37\%), pentadecanoic acid (2.13\%), cis-9-octadecenoic acid (2.13\%), cyclohexanone, 4- methyl, O-methyloxime (2.04\%), 3-nonynoic acid (1.88\%), benzonitrile, 2-(2-pyridinyl) (1.88\%) and ergotaman-3', 6',18-trione,9,10-dihydro-12' -hydroxy-2'-methyl-5' -(phenylmethyl) (1.68\%). (TLC) was carried out to investigate chemical compounds in the extract.

\section{Discussion}

The multi-drug resistance of pathogenic microorganisms is getting more and more severe yearly due to misuse of

Table 3 Identities and morphological characteristics of the endophytic bacterial isolates

\begin{tabular}{|c|c|c|c|c|c|}
\hline Isolates & $\begin{array}{l}\text { Assigned bacterial } \\
\text { Names }\end{array}$ & GenBank accession number & Similarities (\%) & Colony morphology & Gram reaction \\
\hline 1 & Pseudomonas aeruginosa & СР043328.1 & 99 & Rod & Negative \\
\hline 2 & Pseudomonas aeruginosa & СР033432.1 & 97 & Rod & Negative \\
\hline 3 & Pseudomonas aeruginosa & LR657304.1 & 97 & Rod & Negative \\
\hline 4 & $\begin{array}{l}\text { Pseudomonas } \\
\text { Aeruginosa }\end{array}$ & СР044006.1 & 98 & Rod & Negative \\
\hline 5 & $\begin{array}{l}\text { Pseudomonas } \\
\text { aeruginosa }\end{array}$ & СР032126.1 & 98 & Rod & Negative \\
\hline 6 & - & - & - & Rod & Negative \\
\hline 7 & - & - & - & Rod & Positive \\
\hline 8 & - & - & - & Rod & Negative \\
\hline 9 & - & - & - & Rod & Negative \\
\hline 10 & - & - & - & Rod & Negative \\
\hline 11 & - & - & - & Rod & Negative \\
\hline 12 & - & - & - & Rod & Negative \\
\hline 13 & - & - & - & Rod & Negative \\
\hline
\end{tabular}


Table 4 Antibiotic susceptibility pattern of Pseudomonas aeruginosa CP43328.1; inhibition zones

\begin{tabular}{lllllllll}
\hline Isolate & MEM & IML & KF & ETP & DA & K & A & GM \\
\hline & $23 \pm 0.0$ & $24 \pm 0.0$ & 0 & 0 & 0 & $9 \pm 0.0$ & 0 & $18 \pm 1.2$ \\
\hline
\end{tabular}

Key: MEM meropenem, IML imipenem, KF cephalothin, ETP ertapenem, DA clindamycin, $K$ kanamycin, $A$ amoxicillin and $G M$ gentamicin

drugs [40]. Endophytes, especially those from medicinal plants are reported to be prolific producers of variety of metabolites with profound bioactivities. Moreover, their metabolites are biodegradable and easy to be produced on a large scale [41]. Thus, bacterial endophytes from $A$. cordifolia CIX1 were isolated for production of bioactive compounds.

A variety of chemical disinfectants have been employed for surface sterilization of excised plant tissues to remove epiphytes. However, immersion of tissue in ethanol, sodium hypochloride and bicarbonate have shown significant success in different studies [10]. The effectiveness of surface sterilization of the leaves from $A$. cordifolia CIX1 was confirmed as there was no microbial growth observed after 5 days. This indicate that the surface sterility method was effective at inhibiting growth of epiphytic bacteria and fungi. Thus, the subsequence isolates can be considered as true endophytic bacteria. The leaves had CFU value of $9.2 \times 103$ (Table 1 ). The diversity of isolated endophytic bacteria dependent on the media used during isolation [42]. Our results demonstrated that NA did support the growth of endophytic bacteria. Thirteen endophytic strains were isolated from the fresh leaves of $A$. cordifolia CIX1. It can therefore be assumed that the ecological success of $A$. cordifolia CIX1 in the north part of Kwazulu-Natal could not only be associated to the conducive climate and fertile soil but also to its association with active endophytes as they are known to have symbiotic relationship.

Currently, microorganisms are attracting an increasing attention as source of for new enzymes because enzymes derived from microbes are relatively stable and active than corresponding enzymes derived from plants or animals [43]. In the study, the qualitative analysis of enzyme production namely; protease, cellulase, esterase and amylase was done. Most of the isolate tested positive for enzyme production. Our observations are in agreement with previous reports that illustrated endophytes such as Pseudomonas sp. as producers of extracellular

Table 5 Antibacterial activity of the extract evaluated by agar diffusion method

\begin{tabular}{lccll}
\hline concentration & \multicolumn{4}{l}{ Zone of inhibition $(\mathbf{m m})$} \\
\cline { 2 - 5 } & E. coli & P. mirabilis & B. cereus & S. aureus \\
& (ATCC & (ATCC & (ATCC & (ATCC \\
& 25922) & 25933) & 10102) & 25925) \\
\hline $4 \mathrm{mg} / \mathrm{ml}$ & $18 \pm 1.25$ & $17 \pm 1.00$ & $24 \pm 1.41$ & $31 \pm 1.25$ \\
\hline
\end{tabular}

Table 6 MIC and MBC values of the extract against the selected bacterial strains

\begin{tabular}{|c|c|c|c|c|}
\hline \multirow[t]{2}{*}{ Bacteria } & \multicolumn{2}{|l|}{ Extract } & \multicolumn{2}{|c|}{ Ciprofloxacin } \\
\hline & $\begin{array}{l}\text { MIC } \\
(\mathrm{mg} / \mathrm{ml})\end{array}$ & $\begin{array}{l}\mathrm{MBC} \\
(\mathrm{mg} / \mathrm{ml})\end{array}$ & $\begin{array}{l}\text { MIC } \\
(\mathrm{mg} / \mathrm{ml})\end{array}$ & $\begin{array}{l}\mathrm{MBC} \\
(\mathrm{mg} / \mathrm{ml})\end{array}$ \\
\hline B. cereus (ATCC 10102) & $0.098 \pm 0$ & $>50 \pm 0$ & $25 \pm 0$ & $>50 \pm 0$ \\
\hline S. aureus (ATCC 25925) & $0.098 \pm 0$ & $25 \pm 0$ & $25 \pm 0$ & $>50 \pm 0$ \\
\hline E. coli (ATCC 25922) & $0.391 \pm 0$ & $>50 \pm 0$ & $25 \pm 0$ & $>50 \pm 0$ \\
\hline P. mirabilis (ATCC 25933) & $0.391 \pm 0$ & $>50 \pm 0$ & $25 \pm 0$ & $>50 \pm 0$ \\
\hline
\end{tabular}

amylase, esterase, cellulose and proteinase [44]. The hydrolytic enzymes are perceived to play an important role for the colonization of $A$. cordifolia CIX1 by the isolated endophytes.

All the morphologically identified bacterial endophytes were of Pseudomonas sp. The isolate of interest (Isolate 1) exhibited 99\% similarity with Pseudomonas aureuginosa CP043328.1. Most studies have reported that Pseudomonas sp. are one of the main endophytic bacteria often found associated with most of the medicinal plants. Thus, our study affirmed these reports. Endophytic Pseudomonas sp. have been used as biocontrols against phytopathogens [45].

Antimicrobial resistant genes, in addition to clinical pathogens, are also present in environmental isolates. Isolate-P. aureuginosa CP043328.1 was sensitive to meropenem, imipenem and gentamycin (Table 2). This suggest that these compounds (antibiotics) are not present as secondary metabolites in P. aureuginosa CP043328.1. Moreover, these antibiotics can be used if there is an outbreak due to $P$. aureuginosa CP043328.1. Ethyl acetate solvent was used for extraction of the secondary metabolites and the yield was $0.6 \mathrm{~g} / 500 \mathrm{ml}$. Ethyl acetate is the good solvent for extraction of active metabolites from bacterial endophytes as it has medium polarity (dissolve both polar and non- polar active compounds) [46]. In addition to medium polarity, the solvent extract low and high molecular weight polyphenols.

In therapeutic applications, secondary metabolites are significant as they often demonstrate among others, efficacy against multidrug-resistant bacteria. Thus, secondary metabolites from Isolate 1-P. aeruginosa CP043328.1 were extracted and antibacterial potency of the extract was evaluated against the selected bacteria. The extract showed a broad-spectrum activity against all tested bacterial strains (Table 6). It was more pronounced against Gram positive bacterial strains. Gram-negative bacteria, in addition to a thin peptidoglycan layer ( 2 to $7 \mathrm{~nm}$ ), do possess approximately 7 to $8 \mathrm{~nm}$ of the outer membrane. This outer membrane consists of an additional protective lipopolysaccharide layer that exhibits toxicity and antigenicity against antibacterial agents [35]. It was therefore concluded that the resistance shown by the 
Table $\mathbf{7}$ Chemical constituents of the extract

\begin{tabular}{lll}
\hline Number of compounds & Compounds & Area (\%) \\
\hline 1 & Ergotaman-3',6',18-trione,9,10-dihydro-12'-hydroxy-2'-methyl-5'-(phenylmethyl) & 1.68 \\
2 & 3-Nonynoic acid & 1.88 \\
3 & Benzonitrile, 2-(2-pyridinyl) & 1.88 \\
4 & Cyclohexanone, 4-methyl-, O-methyloxime & 2.04 \\
5 & Pentadecanoic acid & 2.13 \\
6 & cis-9-Octadecenoic acid & 2.13 \\
7 & Pyrrolo[1,2-a]pyrazine-1,4-dione, hexahydro-3-(2-methylpropyl \\
8 & L-Proline, N-valeryl-, tetradecyl ester & 2.37 \\
9 & L-Proline, N-valeryl-, undecyl ester & 2.61 \\
10 & Xanthoxylin & 2.82 \\
11 & trans-2-Decenoic acid & 3.74 \\
12 & 2-Dodecenoic acid & 4.57 \\
13 & [1, 2, 4] Oxadiazole, 5-benzyl-3-(thiophen-2-yl) & 5.51 \\
14 & 9-Octadecenamide & 5.70 \\
\hline 5 & Diisooctyl phthalate & 10.44 \\
\hline
\end{tabular}

Gram-negative bacteria as compared to Gram-positive bacteria to the extract was as the result of the mechanism of action of this layer. Gram positive bacteria do not possess this layer and therefore they were highly sensitive to the extract. Gram positive bacteria allowed the direct contact of the extract constituents with the phospholipid bilayer of the cell membrane, enabling the extract to inhibit bacterial growth easily. Microbial and plant extracts that have noteworthy antibacterial activities are those with MIC values less than $1 \mathrm{mg} / \mathrm{ml}$ [47]. Thus, the profound activity of the extract suggests the potential use as a therapeutic agent since it demonstrated MIC values in a range of $0.098-0.391 \mathrm{mg} / \mathrm{ml}$ against the selected pathogens. Moreover, it is interesting to note that ciprofloxacin had higher MIC value (25 $\mathrm{mg} / \mathrm{ml}$ ) against the tested strains when compared to the extract. This implied that that the bacterial strains had developed ciprofloxacin resistance and affirms the need for novel antibacterial agents. Furthermore, the extract exhibited bactericidal effect against S. aureus (ATCC 25925) with the MBC of $25 \mathrm{mg} / \mathrm{ml}$.

Compounds with scavenging activities against free radicals have gained constant attention in recent years. These compounds have potential to nullify disease progression caused by excess free radicals [48, 49]. Since there are few studies investigating the antioxidant activity of extracts from endophytic microorganisms, the evaluation of antioxidant activity of the extract was imperial. The extract showed poor activity against DPPH radical (Fig. 1) and moderate activity against ABTS radical (Fig. 2). Molyneux, 2004 classified the antioxidant activity where the highly active compounds have $\mathrm{IC}_{50}$ values $<0.05 \mathrm{mg} / \mathrm{ml}$, the active category have $\mathrm{IC}_{50}$ values of $0.05-0.1 \mathrm{mg} / \mathrm{ml}$, medium category have $\mathrm{IC}_{50}$ values of

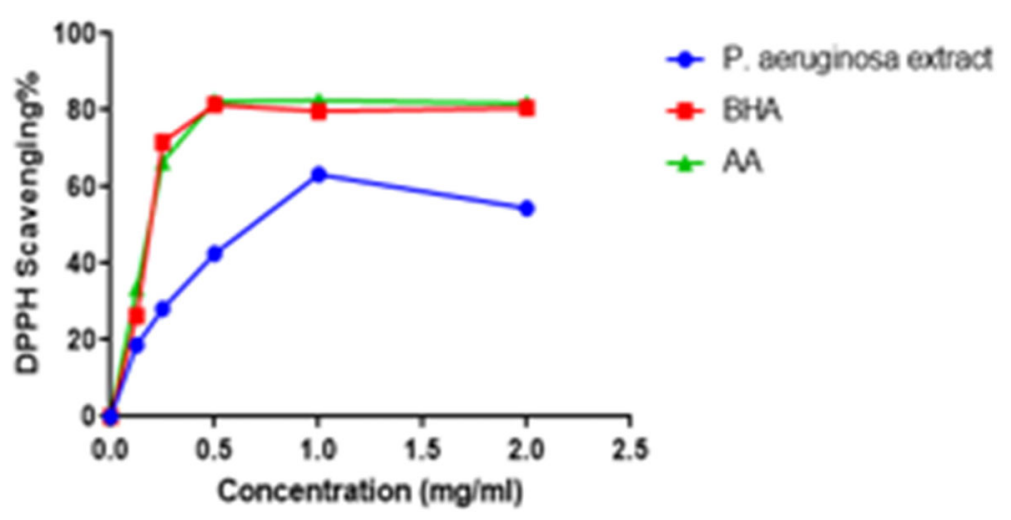

Fig. 1 DPPH scavenging activity of the extract, ascorbic acid and BHA 


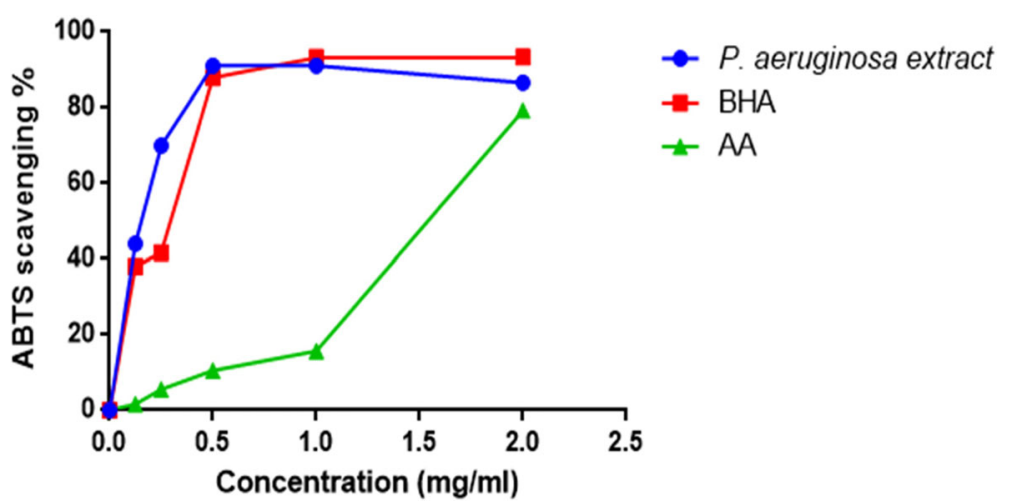

Fig. 2 ABTS scavenging activity of the extract, ascorbic acid and BHA

$0.1-0.15 \mathrm{mg} / \mathrm{ml}$, and weak categories have $\mathrm{IC}_{50}$ values of $0.151-0.2 \mathrm{mg} / \mathrm{ml}$. Thus, the results clearly show that the extract has promising ABTS scavenging activity and could be a potential source of natural antioxidant.

Pseudomonas aeruginosa is known for producing a wide variety of metabolites with antimicrobial and antioxidant effects. The identified volatile compounds, xanthoxylin, trans-2-decenoic acid, [1, 2, 4] oxadiazole, 5-benzyl-(thiophen-2-yl), dodecenoic acid, 3-nonynoic, pyrrolo [1,2-a]pyrazine-1,4-dione, hexahydro-3-(2methylpropyl), pentadecanoic acid and diisooctyl phthalate are recognised for possession of antimicrobial activity [50-57]. cis-9-Octadecenoic acid, 2-dodecenoic acid and 9-octadecenamide are reported to possess antioxidant property $[58,59]$. It was therefore assumed that the profound antibacterial and antioxidant activity of extract was due to synergistical activities of the identified bioactive compounds.

\section{Conclusions}

Out of 13 isolates, Isolate 1 ( $P$. aeruginosa CP43328.1) produced all the tested enzymes and showed the ability to produce antimicrobials that were effective against all the tested pathogens. Its secondary metabolites demonstrated antibacterial activity with MIC values ranging from $0.098-0.391 \mathrm{mg} / \mathrm{ml}$. It had bactericidal effect against S. aureus (ATCC 25925) at $25 \mathrm{mg} / \mathrm{ml}$. It also illustrated potent $\mathrm{ABTS}$ scavenging activity with an $\mathrm{IC}_{50}$ value of $0.051 \mathrm{mg} / \mathrm{ml}$. The extract showed a total of 15 volatile compounds with diisooctyl phthalate (50.51\%) and $[1,2,4]$ oxadiazole, 5-benzyl-3 (10.44\%) being the major compounds. P. aeruginosa $\mathrm{CP} 43328.1$ has a potential to serve as a source of pharmacologically important compounds. Further studies, quantitative analysis of the detected enzymes and evaluation of the mechanisms involved in antibacterial activity are imperial.

\section{Abbreviations}

NA: nutrient agar; MH: Mueller Hinton; CFU: colony forming units; TLC: thin layer chromatography; NCBI: National Center for Biotechnology Information;
MIC: minimum inhibitory concentration; MBC: minimum bactericidal concentration; ATCC: American Type Culture Collection; DMSO: dimethyl sulfoxide; INT: piodonitrotetrazodium violet; $I_{50}$ : half maximal inhibitory concentration; ABTS: 2, 2'-azinobis (3-ethylbenzothiazoline-6-sulfonic acid); BHA: butylated hydroxyl anisole; MEM: meropenem; IML: imipenem; OB: cloxacillin; KF: cephalothin; ETP: ertapenem; DA: clindamycin; CLSI: Clinical Laboratory Standards Institute; BLAST: basic local alignment search tool

\section{Acknowledgements}

I would like to acknowledge our laboratory mates- Medical Microbiology Group for outstanding support throughout the course.

\section{Authors' contributions}

The study was conceived and designed by TSM and JSES. The experiments were conducted by CIN and LSN. TSM analysed the data. TSM and JSS contributed to study design, data analysis, and revising the manuscript. All authors read and approved the final manuscript.

\section{Funding}

This work was supported by the University of Zululand, and Future Planning (MSIP) National Research Foundation of South Africa (NRF) (Grant reference: HBG 181011371909). The funding bodies have no role in the design of the study and collection, analysis, and interpretation of data in writing the manuscript, which are fully the responsibilities of the authors.

Availability of data and materials

The datasets used and/or analysed during the current study available from the corresponding author on reasonable request.

Ethics approval and consent to participate

Not applicable.

Consent for publication

Not applicable.

\section{Competing interests}

The authors declare that they have no competing interests.

Received: 21 January 2020 Accepted: 27 September 2020

Published online: 07 October 2020

\section{References}

1. Organization WH: WHO Country Cooperation Strategy 2016-2020: South Africa 2016.

2. Organization WH: Antimicrobial resistance and primary health care: brief. In: World Health Organization; 2018.

3. Bisi-Johnson MA, Obi CL, Samuel BB, Eloff JN, Okoh Al. Antibacterial activity of crude extracts of some south African medicinal plants against multidrug resistant etiological agents of diarrhoea. BMC Complement Altern Med. 2017;17(1):321 . 
4. Holmes KK, Bertozzi S, Bloom BR, Jha P, Gelband H, DeMaria LM, Horton S: Major infectious diseases: key messages from Disease Control Priorities, vol. 9: World Bank Washington, DC; 2017.

5. Newman DJ. Are microbial endophytes the actual producers of bioactive antitumor agents. Trends Cancer. 4(10):662-70.

6. Gouda S, Das G, Sen SK, Shin H-S, Patra JK. Endophytes: a treasure house of bioactive compounds of medicinal importance. Front Microbiol. 2016;7: 1538.

7. Singh M, Kumar A, Singh R, Pandey KD. Endophytic bacteria: A new source of bioactive compounds. 3 Biotech. 2017;7(5):315.

8. Buatong J, Phongpaichit S, Rukachaisirikul V, Sakayaroj J. Antimicrobial activity of crude extracts from mangrove fungal endophytes. World J Microbiol Biotechnol. 2011;27(12):3005-8.

9. Bundale S, Begde D, Nashikkar N, Kadam T, Upadhyay A. Optimization of culture conditions for production of bioactive metabolites by Streptomyces spp. isolated from soil. Advances Microbiol. 2015;5(06):441.

10. Saini P, Gangwar M, Kalia A, Singh N, Narang D. Isolation of endophytic actinomycetes from Syzygium cumini and their antimicrobial activity against human pathogens. J Applied Natural Sci. 2016:8(1):416-22.

11. Feher M, Schmidt JM. Property distributions: differences between drugs, natural products, and molecules from combinatorial chemistry. J Chem Inf Comput Sci. 2003;43(1):218-27.

12. Bilal S, Ali L, Khan AL, Shahzad R, Asaf S, Imran M, Kang SM, Kim SK, Lee IJ. Endophytic fungus Paecilomyces formosus LHL10 produces sester-terpenoid YW3548 and cyclicpeptide that inhibit urease and a-glucosidase enzyme activities. Arch Microbiol. 2018;200:1493-502.

13. Boyoma FF, Toghueo RMK, Zabalgogeazcoa I, Vázquez de Aldanab BR. Enzymatic activity of endophytic fungi from the medicinal plants Terminalia catappa, Terminalia mantaly and Cananga odorata. South Afr J Botany. 2017:109:146-53.

14. Bhoonobtong A, Sawadsitang S, Sodngam S, Mongkolthanaruk W. Characterization of endophytic bacteria, Bacillus amyloliquefaciens for antimicrobial agents production. In: International Conference on Biological and Life Sciences, vol. 2012; 2012. p. 6-11.

15. Ryan RP, Germaine K, Franks A, Ryan DJ, Dowling DN. Bacterial endophytes: recent developments and applications. FEMS Microbiol Lett. 2008;278(1):1-9.

16. Garmana AN, Sukandar EY, Fidrianny I. Activity of several plant extracts against drug- sensitive and drug-resistant microbes. Procedia Chemistry. 2014;13:164-9.

17. Horng C-T, Chao H-R, Lee C-F, Hsueh C-W, Chen F-A. Gastro protective effect of madeira vine against ethanol-induced gastric mucosal lesion in rat. Asian J Chem. 2012;24(2):765.

18. Qiong G, Yun-Bao M, Xue-Mei M, Rui-Rui W, Jun Z, Yong-Tang M, Ji-Jun C. One new flavanoid and anti-HIV active constituents from Boussingaultia gracilis miers var. Pseudobaselloides bailey. 2007.

19. Astuti SM, Sakinah MA, Andayani RB, Risch A. Determination of saponin compound from Anredera cordifolia (ten) Steenis plant (binahong) to potential treatment for several diseases. J Agric Sci. 2011;3(4):224.

20. Laksmitawati DR, Widyastuti A, Karami N, Afifah E, Rihibiha DD, Nufus H, Widowati W. Anti-inflammatory effects of Anredera cordifolia and Piper crocatum extracts on lipopolysaccharide-stimulated macrophage cell line. Bangladesh J Pharmacol. 2017;12(1):35-40.

21. Istyastono EP, Yuliani SH: Scarless wound healing gel with Binahong (Anredera cordifolia (Ten) Steenis) leaves extract and celecoxib as the active ingredients. In: AIP Conference Proceedings: 2016: AIP Publishing; 2016: 160001.

22. Djamil R, Wahyudi P, Wahono S, Hanafi M. Antioxidant activity of flavonoid from Anredera cordifolia (ten) Steenis leaves. Int Res J Pharmacy. 2012;3(9): 241-3.

23. Lestari D, Sukandar EY, Fidrianny I. Anredera cordifolia leaves extract as antihyperlipidemia and endothelial fat content reducer in male Wistar rat. Internation J Pharmaceutical Clin Res. 2015;7(6):435-9.

24. Djamil R, Winarti W, Zaidan S, Abdillah S. Antidiabetic activity of flavonoid from Binahong leaves (Anredera cordifolia) extract in alloxan induced mice. J Pharmacognosy Natural Products. 2017;3(2):1-4.

25. Tanvir R, Sajid I, Hasnain S. Screening of endophytic Streptomycetes isolated from Parthenium hysterophorus L. against nosocomial pathogens. Pakistan J Pharmaceutical Sci. 2013;26(2):277-83.

26. Vaidya S, Rathore P: Isolation, screening and characterization of amylase producing bacteria from soil of potato dump sites from different regions of madhya pradesh. In Conference Paper 2015.
27. Vijayaraghavan P, Samuel GPV. A simple method for the detection of protease activity on agar plates using bromocresolgreen dye. J Biochem Technol. 2013;4(3):628-30.

28. Zamani $\mathrm{H}$, Salehzadeh A, Abdolhosseini M: Isolation and molecular identification of a cellulotic bacterium from muncipal waste and investigation of its cellulose production. Bioscience J 2018, 34(3). https://doi. org/10.14393/BJv34n3a2018-40007.

29. Sierra G. A simple method for the detection of lipolytic activity of microorganisms and some observations on the influence of the contact between cells and fatty substrates. Antonie Van Leeuwenhoek. 1957;23(1):15-22.

30. Muzzamal H, Sarwar R, Sajid I, Hasnain S. Isolation, identification and screening of endophytic bacteria antagonistic to biofilm formers. Pakistan J Zool. 2012;44(1):2012.

31. Buchanan RE, Gibbons NE. Bergey's of determinative bacteriology. New York: United States of America; 1974. p. 529-63.

32. Altschul SF, Madden TL, Schäffer AA, Zhang J, Zhang Z, Miller W, Lipman DJ. Gapped BLAST and PSI-BLAST: a new generation of protein database search programs. Nucleic Acids Res. 1997;25(17):3389-402.

33. Papich MG. Performance standards for antimicrobial disk and dilution susceptibility tests for bacteria isolated from animals: clinical and laboratory standards institute; 2015.

34. Kim HY, Choi G, Lee H, Lee SW, Lim H, Jang K, Son S, Lee S, Cho K, Sung N. Some fungal endophytes from vegetable crops and their anti-oomycete activities against tomato late blight. Lett Appl Microbiol. 2007;44(3):332-7.

35. Maliehe TS, Shandu JS, Basson AK, Simelane MB, Lazarus G, Singh M. Pharmacodynamic and cytotoxicity effects of Syzygium cordatum \{S Ncik, 48 (UZ) \} fruit-pulp extract in gastrointestinal tract infections. Trop J Pharm Res. 2017:16:1349-55.

36. Eloff JN. A sensitive and quick microplate method to determine the minimal inhibitory concentration of plant extracts for bacteria. Planta Med. 1998;64(08):711-3.

37. Brand-Williams W, Cuvelier ME, Berset CLWT. Use of a free radical method to evaluate antioxidant activity. LWT-Food Sci Technol. 1995;28(1):25-30.

38. Re R, Pellegrini N, Proteggente A, Pannala A, Yang M, Rice-Evans C. Antioxidant activity applying an improved ABTS radical cation decolorization assay. Free Radic Biol Med. 1999;26(9-10):1231-7.

39. Tsilo PH, Maliehe TS, Shandu JS, Khan R. Chemical composition and some biological activities of the methanolic Encephalartos ferox fruit extract. Pharmacognosy J. 2020;12(5):2020.

40. Golinska P, Wypij M, Agarkar G, Rathod D, Dahm H, Rai M. Endophytic actinobacteria of medicinal plants: diversity and bioactivity. Antonie Van Leeuwenhoek. 2015

41. Katoch M, Singh G, Sharma S, Gupta N, Sangwan PL, Saxena AK. Cytotoxic and antimicrobial activities of endophytic fungi isolated from Bacopa monnieri (L.) Pennell (Scrophulariaceae). BMC Complementary Alternative Med. 2014;14(1):52.

42. Wang SS, Liu JM, Sun J, Sun YF, Liu JN, Jia N, Dai XF. Diversity of culture independent bacteria and antimicrobial activity of culturable endophytic bacteria isolated from different Dendrobium stems. Sci Rep. 2019;9(1):1-12.

43. Castro RA, Quecine MC, Lacava PT, Batista BD, Luvizotto DM, Marcon J, Ferreira A, Melo IS, Azevedo JL. Isolation and enzyme bioprospection of endophytic bacteria associated with plants of Brazilian mangrove ecosystem. SpringerPlus. 2014;3(1):382.

44. El-Deeb B, Bazaid S, Gherbawy Y, Elhariry H. Characterization of endophytic bacteria associated with rose plant (Rosa damascena trigintipeta) during flowering stage and their plant growth promoting traits. J Plant Interact. 2012;7(3):248-53.

45. Mercado-Blanco J, JJ Lugtenberg B: Biotechnological applications of bacterial endophytes. Current Biotechnol 2014, 3(1):60-75.

46. Ramachandran G, Rajivgandhi G, Maruthupandy M, Manoharan N. Extraction and partial purification of secondary metabolites from endophytic actinomycetes of marine green algae Caulerpa racemosa against multi drug resistant uropathogens. Biocatalysis Agricultural Biotechnol. 2019;17:750-7.

47. Uche-Okereafor N, Sebola T, Tapfuma K, Mekuto L, Green E, Mavumengwana $V$. Antibacterial activities of crude secondary metabolite extracts from Pantoea species obtained from the stem of Solanum mauritianum and their effects on two Cancer cell lines. Int J Environ Res Public Health. 2019;16(4):602.

48. Wilson R. Free radicals and tissue damage, mechanistic evidence from radiation studies. Biochem Mechanisms Liver Injury. 1998; pp. 123-25. 
49. Mariani E, Polidori M, Cherubini A, Mecocci P. Oxidative stress in brain aging, neurodegenerative and vascular diseases: an overview. J Chromatogr B. 2005;827(1):65-75.

50. dos Reis CM, da Rosa BV, da Rosa GP, do Carmo G, LMB M, Ugalde GA, Kuhn KR, Morel AF, Jahn SJ, Kuhn RC. Antifungal and antibacterial activity of extract produced from Diaporthe schini. J Biotechnol. 2019;294:20-37.

51. Sugiyama T, Takahashi K, Mori H. Royal jelly acid, 10-hydroxy-trans-2decenoic acid, as a modulator of the innate immune responses. Endocrine Metabolic Immune Disorders. 2012;12(4):368-76.

52. Hussein A, Mohammed O, Hadi GJ, Hameed $I H$. Phytochemical screening of methanolic dried pgalls extract of Quercus infectoria using gas chromatography-mass spectrometry (GC-MS) and Fourier transform-infrared (FT-IR). J Pharmacognosy Phototherapy. 2016;8(3):49-59.

53. Dash S, Jin C, Lee OO, Xu Y, Qian PY. Antibacterial and antilarval-settlement potential and metabolite profiles of novel sponge-associated marine bacteria. J Ind Microbiol Biotechnol. 2009;36(8):1047-56.

54. Belakhdar G, Benjouad A, Abdennebi EH. Determination of some bioactive chemical constituents from Thesium humile Vahl. J Materials Environmental Sci. 2015;6(10):2778-83.

55. Altaee N, Kadhim MJ, Hameed $\Vdash H$. Detection of volatile compounds produced by Pseudomonas aeruginosa isolated from UTI patients by gas chromatography-mass spectrometry. Int J Toxicological Pharmacy Res. 2017; 7(6):8-24.

56. Leemans E, Mahasenan KV, Kumarasiri M, Spink E, Ding D, O'Daniel PI, Lee M. Three-dimensional QSAR analysis and design of new 1, 2, 4-oxadiazole antibacterials. Bioorganic Med Chem Letters. 2016;26(3):1011-5.

57. Moniot S, Forgione M, Lucidi A, Hailu GS, Nebbioso A, Carafa V, Pellicciari R. Development of 1, 2,4-oxadiazoles as potent and selective inhibitors of the human deacetylase sirtuin 2: structure-activity relationship, X-ray crystal structure, and anticancer activity. J Medical Chemistry. 2017;60(6):2344-60.

58. Abou-Elela GM, Abd-Elnaby H, Ibrahim HA, Okbah MA. Marine natural products and their potential applications as anti-infective agents. World Appl Sci J. 2009:7(7):872-80.

59. Özçelik B, Aslan M, Orhan I, Karaoglu T. Antibacterial, antifungal, and antiviral activities of the lipophylic extracts of Pistacia vera. Microbiol Res. 2005;160(2):159-64.

\section{Publisher's Note}

Springer Nature remains neutral with regard to jurisdictional claims in published maps and institutional affiliations.

Ready to submit your research? Choose BMC and benefit from:

- fast, convenient online submission

- thorough peer review by experienced researchers in your field

- rapid publication on acceptance

- support for research data, including large and complex data types

- gold Open Access which fosters wider collaboration and increased citations

- maximum visibility for your research: over $100 \mathrm{M}$ website views per year

At $\mathrm{BMC}$, research is always in progress.

Learn more biomedcentral.com/submissions 